\title{
Desulfomusa hansenii gen. nov., sp. nov., a novel marine propionate-degrading, sulfate-reducing bacterium isolated from Zostera marina roots
}

Department of Microbial Ecology, Institute of Biological Sciences, University of Aarhus, 8000 Aarhus, Denmark

\author{
Kai Finster, Trine R. Thomsent and Niels Birger Ramsing
}

Author for correspondence: Kai Finster. Tel: +45 8942 3241. Fax: +458612 7191 e-mail: Kai.Finster@biology.au.dk

The physiology and phylogeny of a novel sulfate-reducing bacterium, isolated from surface-sterilized roots of the marine macrophyte Zostera marina, are presented. The strain, designated $\mathrm{P}^{\top}$, was enriched and isolated in defined oxygen-free, bicarbonate-buffered, iron-reduced seawater medium with propionate as sole carbon source and electron donor and sulfate as electron acceptor. Strain $\mathrm{P}^{\top}$ had a rod-shaped, slightly curved cell morphology and was motile by means of a single polar flagellum. Cells generally aggregated in clumps throughout the growth phase. $\mathrm{High} \mathrm{CaCl}_{2}(10 \mathrm{mM})$ and $\mathrm{MgCl}_{2}(50 \mathrm{mM})$ concentrations were required for optimum growth. In addition to propionate, strain $\mathrm{P}^{\top}{ }^{\top}$ utilized fumarate, succinate, pyruvate, ethanol, butanol and alanine. Oxidation of propionate was incomplete and acetate was formed in stoichiometric amounts. Strain $\mathrm{P}^{\top}{ }^{\top}$ thus resembles members of the sulfatereducing genera Desulfobulbus and Desulforhopalus, which both oxidize propionate incompletely and form acetate in addition to $\mathrm{CO}_{2}$. However, sequence analysis of the small-subunit rDNA and the dissimilatory sulfite reductase gene revealed that strain $\mathrm{P}^{\top}{ }^{\top}$ was unrelated to the incomplete oxidizers Desulfobulbus and Desulforhopalus and that it constitutes a novel lineage affiliated with the genera Desulfococcus, Desulfosarcina, Desulfonema and 'Desulfobotulus'. Members of this branch, with the exception of 'Desulfobotulus sapovorans', oxidize a variety of substrates completely to $\mathrm{CO}_{2}$.

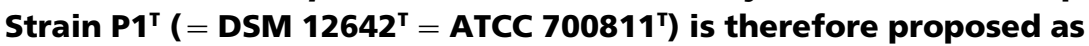
Desulfomusa hansenii gen. nov., sp. nov. Strain $\mathrm{P}^{\top}{ }^{\top}$ thus illustrates the difficulty of extrapolating rRNA similarities to physiology and/or ecological function.

Keywords: propionate, Desulfobulbus, incomplete oxidation, Desulfomusa hansenii gen. nov., sp. nov

\section{INTRODUCTION}

High sulfate reduction rates have been measured in the rhizosphere of numerous marine macrophytes (Blaabjerg et al., 1998 and references therein) and with isolated roots of the eelgrass Zostera marina, Zostera

\footnotetext{
† Present address: Environmental Engineering Laboratory, Aalborg University, Sohngaardsholmsvej 57, DK-9000 Aalborg, Denmark.

Abbreviations: DSR, dissimilatory sulfite reductase; SSU, small subunit. The GenBank accession numbers of the 16S rDNA sequence and the dissimilatory sulfite reductase gene sequence of strain $\mathrm{P} 1^{\top}$ are $A F 321820$ and AF321819, respectively.
}

noltii and Spartina maritima (Blaabjerg \& Finster, 1998; Nielsen et al., 2001). Despite this fact, only a few studies have been carried out describing sulfatereducer populations in these habitats. For instance, Hines et al. (1999), investigating the population composition and biogeochemistry of sulfate-reducing bacteria in the rhizosphere of Spartina alterniflora, found that the majority of the rRNA from sulfate-reducing bacteria was from members of the family Desulfobacteriaceae. In a previous study, Rooney-Varga et al. (1997) showed that within the family Desulfobacteriaceae, rRNA clones related to the Desulfosarcina/Desulfococcus/Desulfonema assemblage pre- 
dominated. In both papers, the authors used genetic data to speculate upon the ecological role and the physiology of the organisms from which the rRNA was derived. They concluded that members of the Desulfosarcina / Desulfococcus / Desulfonema assemblage that have a versatile substrate spectrum are particularly well adapted to the rhizosphere environment. The number of isolated sulfate reducers from rhizosphere environments is even more limited. Recently, Nielsen et al. (1999) reported on the isolation and characterization of a fructose-degrading sulfate reducer from the cortex of Zostera marina roots, Desulfovibrio zosterae sp. nov. Desulfovibrio zosterae is, to our knowledge, the only sulfate reducer that has been isolated from root tissue of a marine macrophyte. From the same batch of surface-sterilized roots from which Desulfovibrio zosterae was isolated, a propionate-degrading sulfate reducer, designated strain $\mathrm{P}^{\mathrm{T}}$, was also enriched and isolated. The following communication reports on the characterization of this micro-organism. Interestingly, strain $\mathrm{P} 1^{\mathrm{T}}$ shared many phenotypic traits with the incomplete oxidizing genera Desulfobulbus and Desulforhopalus, but was affiliated phylogenetically with the complete oxidizing members of the Desulfosarcina/ Desulfococcus/Desulfonema assemblage.

\section{METHODS}

Source of organisms. Strain $\mathrm{P} 1^{\mathrm{T}}$ was isolated from a mixed culture obtained from surface-sterilized roots of the eelgrass Zostera marina. Root surface sterility was achieved by washing sediment-free roots in a saline $1.05 \%(\mathrm{w} / \mathrm{v})$ hypochlorite solution for $30 \mathrm{~s}$ (Blaabjerg \& Finster, 1998). Isolation of strain $\mathrm{P} 1^{\mathrm{T}}$ was achieved by repeated application of the agar-shake dilution method in an iron-rich APW medium previously described by Coates et al. (1995). Propionate $(10 \mathrm{mM})$ and sulfate $(10 \mathrm{mM})$ served as electron donor/carbon source and electron acceptor, respectively. Colonies of sulfate reducers were identified by their black colour due to ferrous sulfide precipitation. Six morphologically identical strains were isolated. One strain, designated strain $\mathrm{P} 1^{\mathrm{T}}$, was studied in detail. Culture purity was examined in sulfate-free APW medium, which was supplemented with fumarate $(5 \mathrm{mM})$, pyruvate $(5 \mathrm{mM})$, glucose $(5 \mathrm{mM})$ and $0 \cdot 1 \%(\mathrm{w} / \mathrm{w})$ yeast extract. In addition, cultures were regularly checked for purity by phase-contrast microscopy.

Desulfovibrio desulfuricans subsp. desulfuricans DSM 1926 was obtained from the Deutsche Sammlung von Mikroorganismen und Zellkulturen (DSMZ), Braunschweig, Germany. It was used as a positive control in the desulfoviridin test. Rhodococcus sp. was obtained from our own culture collection. It served as a positive control in the Gram-staining test.

Culture medium and substrates. Pure cultures of strain $\mathrm{P} 1^{\mathrm{T}}$ were routinely cultivated in defined APW medium described by Coates et al. (1995), with the modification that iron was only added to the enrichment medium in trace amounts. The modification, which did not affect growth of strain $\mathrm{P}^{\mathrm{T}}$ allowed measurement of the population density by OD determination. Iron as reducing agent was replaced by $\mathrm{Na}_{2} \mathrm{~S} \cdot 9 \mathrm{H}_{2} \mathrm{O}$. The medium was prepared according to
Widdel \& Bak (1992). The following sterile solutions were added aseptically to 11 autoclaved salt medium: $\mathrm{NaHCO}_{3}$ solution $(1 \mathrm{M}), 30 \mathrm{ml} ; \mathrm{Na}_{2} \mathrm{~S}$ solution $(0 \cdot 2 \mathrm{M}), 7 \cdot 5 \mathrm{ml}$; trace metal solution, $1 \mathrm{ml}$ (SL 10a); vitamin solutions; and selenite-tungstate solution $(0.02 \mathrm{mM}), 1 \mathrm{ml}$. The medium was distributed into $50 \mathrm{ml}$ bottles. The bottles were closed with rubber-sealed aluminium screw caps. Electron donors, carbon sources and acceptors were added from sterile stock solutions to give the concentrations desired.

Electron donor and acceptor tests. Electron donor/acceptor tests were carried out in $20 \mathrm{ml} \mathrm{screw}$-capped test tubes in duplicate. Hydrogen consumption was studied in $50 \mathrm{ml}$ glass bottles containing $20 \mathrm{ml}$ medium and a headspace filled with a mixture of hydrogen gas and $\mathrm{CO}_{2}(90: 10 \mathrm{v} / \mathrm{v})$. Acetate $(1 \mathrm{mM})$ was added as carbon source. Substrate fermentation was tested in sulfate-free medium. Controls contained basal medium and inoculum but no additional electron donor or acceptor. Diazotrophic growth was tested for in $\mathrm{NH}_{4} \mathrm{Cl}$-free medium.

Analytical procedures. Propionate and acetate were analysed by ion-exclusion chromatography using an Aminex HPX$87 \mathrm{H}$ column (Bio-Rad) for compound separation. $\mathrm{H}_{2} \mathrm{SO}_{4}$ $(0.05 \mathrm{mM})$ was used as eluent. The flow rate was $0.9 \mathrm{ml}$ $\min ^{-1}$, oven temperature was $65^{\circ} \mathrm{C}$ and the injected sample volume was $100 \mu \mathrm{l}$. The compounds were measured with a UV detector at $210 \mathrm{~nm}$. The samples were centrifuged and filter-sterilized $(0 \cdot 2 \mu \mathrm{m})$ prior to analyses. Sulfate was determined by suppressed ion chromatography as described by Isaksen \& Finster (1996). The $\mathrm{pH}$, salt and temperature tolerances of strain $\mathrm{P} 1^{\mathrm{T}}$ were studied by growth tests in which the change in $\mathrm{OD}_{600}$ was monitored. Experiments were carried out in duplicate. Generation times were calculated from the increase in culture OD over time. Polyglucose was determined as glucose equivalents. Exponentially grown cells were harvested by centrifugation, washed in fresh medium and treated with $1 \mathrm{M} \mathrm{H}_{2} \mathrm{SO}_{4}$ for $6 \mathrm{~h}$. Glucose was measured by a UV method according to the manufacturer's instructions (Boehringer Mannheim). The presence of poly- $\beta$-hydroxybutyrate was examined by staining cells with Sudan black B made up in ethylene glycol and microscopic inspection of the stained specimen. The appearance of red fluorescence in light of $366 \mathrm{~nm}$ after cells were treated with $2 \mathrm{M} \mathrm{NaOH}$ was used to determine the presence of desulfoviridin (Widdel \& Pfennig, 1984). Catalase was assayed by treating a dense cell suspension with few drops of a $3 \% \mathrm{H}_{2} \mathrm{O}_{2}$ solution and examination of bubble formation.

The $\mathrm{G}+\mathrm{C}$ content was determined at the DSMZ according to a standard protocol, which included methods developed by Mesbah et al. (1989), Tamaoka \& Komagata (1984) and Visuvanathan et al. (1989).

Electron microscopy. Whole-cell photographs were obtained with cells that were fixed on a carbon/celloidin-impregnated copper grid (Electron Microscopy Sciences) and stained with uranyl acetate. TEM pictures were taken with a Philips CM 20 transmission electron microscope operating at $120 \mathrm{keV}$. Thin sections were prepared according to standard methodologies. Pictures were taken with a Zeiss 10 b transmission electron microscope.

Nucleic acid extraction, PCR amplification and sequencing. Nucleic acids were extracted using the FastDNA spin kit for soil (Bio 101) according to the manufacturer's instructions. The small-subunit (SSU) rDNA was PCR-amplified and sequenced as described by Lane (1991). A sequence of $1519 \mathrm{nt}$ was obtained after sequencing both strands with 
multiple primers. The dissimilatory sulfite reductase (DSR) gene was amplified using the selective primers designed by Wagner et al. (1998). Direct sequencing of the DSR gene only produced short sequences. Therefore, DSR amplificates were ligated into a pCR-XL-TOPO vector and transformed into ONE SHOT Escherichia coli cells according to the manufacturer's directions (TOPO XL PCR Cloning; Invitrogen). Randomly selected clones containing inserts of the right length were sequenced with a thermosequenase fluorescent cycle sequencing kit (Pharmacia Biotech) and an ALFexpress DNA sequencer (Pharmacia Biotech). A partial sequence of $1263 \mathrm{nt}$ was obtained.

Phylogenetic analysis. rDNA sequences were aligned to the RDP alignment version 7.1 using the on-line services of RDP (http://www.cme msu.edu/rdp/). Sequences from close relatives and phylogenetically representative SSU were also obtained from RDP. The alignment was corrected manually with SEQPUP version 0.6 . Only sequence positions that were unambiguously aligned were included in the phylogenetic analysis. DSR nucleotide sequences were translated to amino acids and aligned manually with the Genetic Data Environment version 2.2 sequence editor implemented in the ARB software environment (January 1996 version; Strunk \& Ludwig, 1998). Trees of both SSU rDNA sequences and DSR amino acid sequences were constructed using the program PAUP* version 4.0 (Swofford, 2000). The nucleotide data matrix was analysed by distance matrix and maximum-likelihood approaches, whereas the amino acid matrix was evaluated by parsimony and distance matrix analysis. All analyses used the default settings in PAUP* 4.0. Bootstrap analyses based on 100 replicates were performed with the distance matrix datasets. Branching patterns that were not supported by more than $50 \%$ of the bootstrap runs were eliminated by making multifurcations at the appropriate basal node. This was done to avoid showing phylogenetic affiliations that were not well supported by the data.

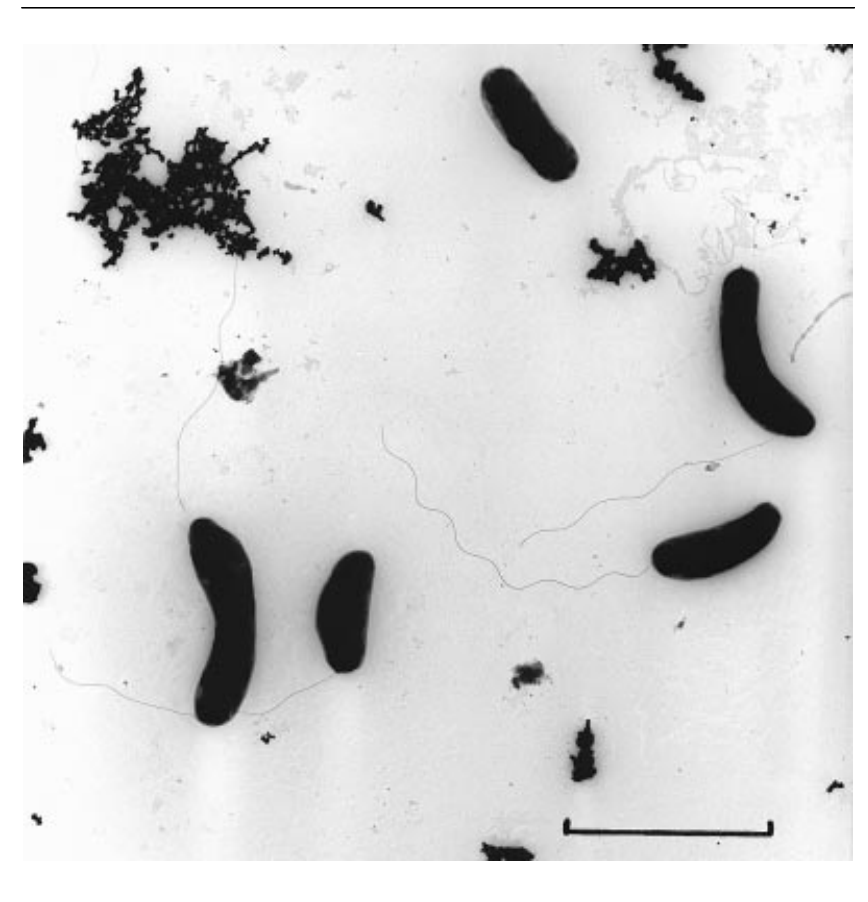

Fig. 1. Electron micrograph of negatively stained cells of strain $\mathrm{P} 1^{\top}$. Bar, $5 \mu \mathrm{m}$.

\section{RESULTS}

\section{Enrichment and isolation}

A sulfate-reducing enrichment culture from surfacesterilized roots of the eelgrass Zostera marina was obtained within 2 weeks of incubation with propionate as electron donor and sulfate as electron acceptor. The culture was dominated by motile, straight to slightly curved, rod-shaped cells. Cells generally aggregated in clumps throughout the growth phase.

\section{Cell morphology}

Cells were straight to slightly curved, 3-6 $\mu \mathrm{m}$ long and $2-3 \mu \mathrm{m}$ wide. They were motile by means of a single polar flagellum (Fig. 1). Cells of old cultures lost their motility. Cells of young cultures were characterized by a spore-like shiny appearance under phase-contrast microscopy. The shiny appearance vanished in old

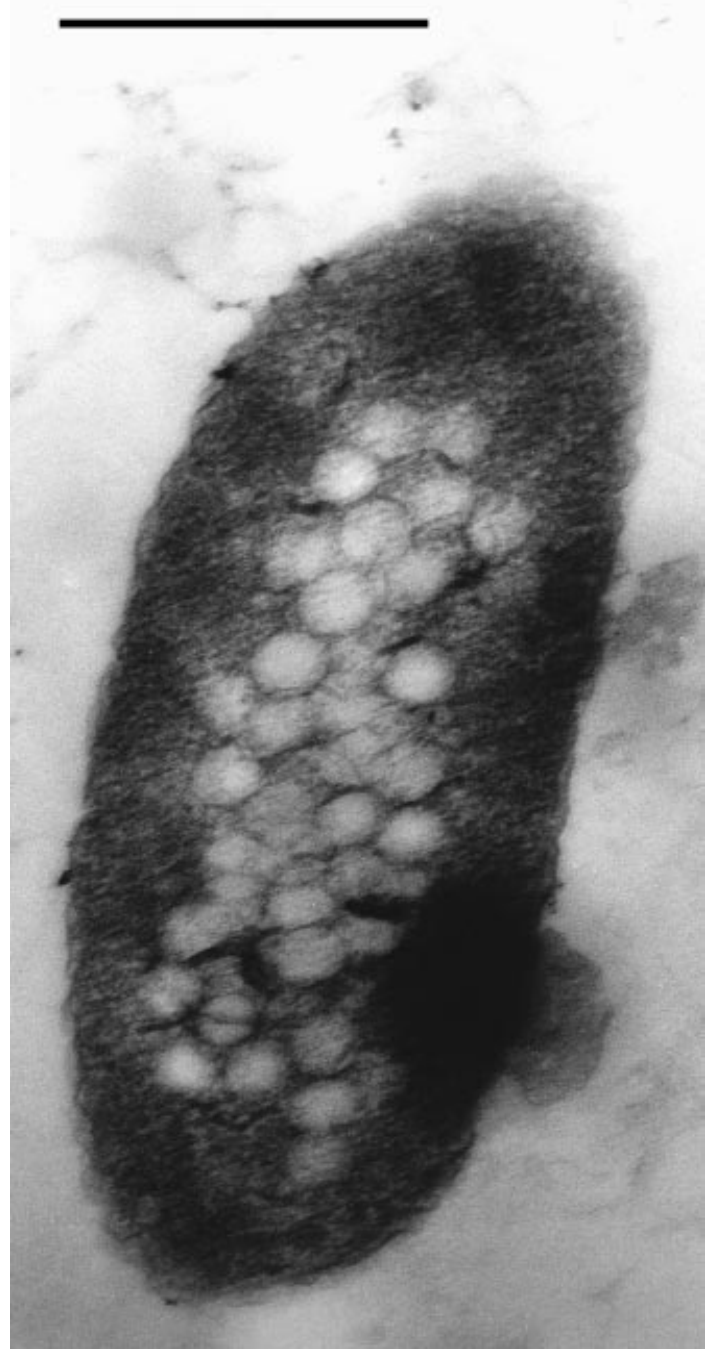

Fig. 2. Electron micrograph of a thin section of strain $P 1^{\top}$ with bright spherical inclusions. Bar, $1 \mu \mathrm{m}$. 


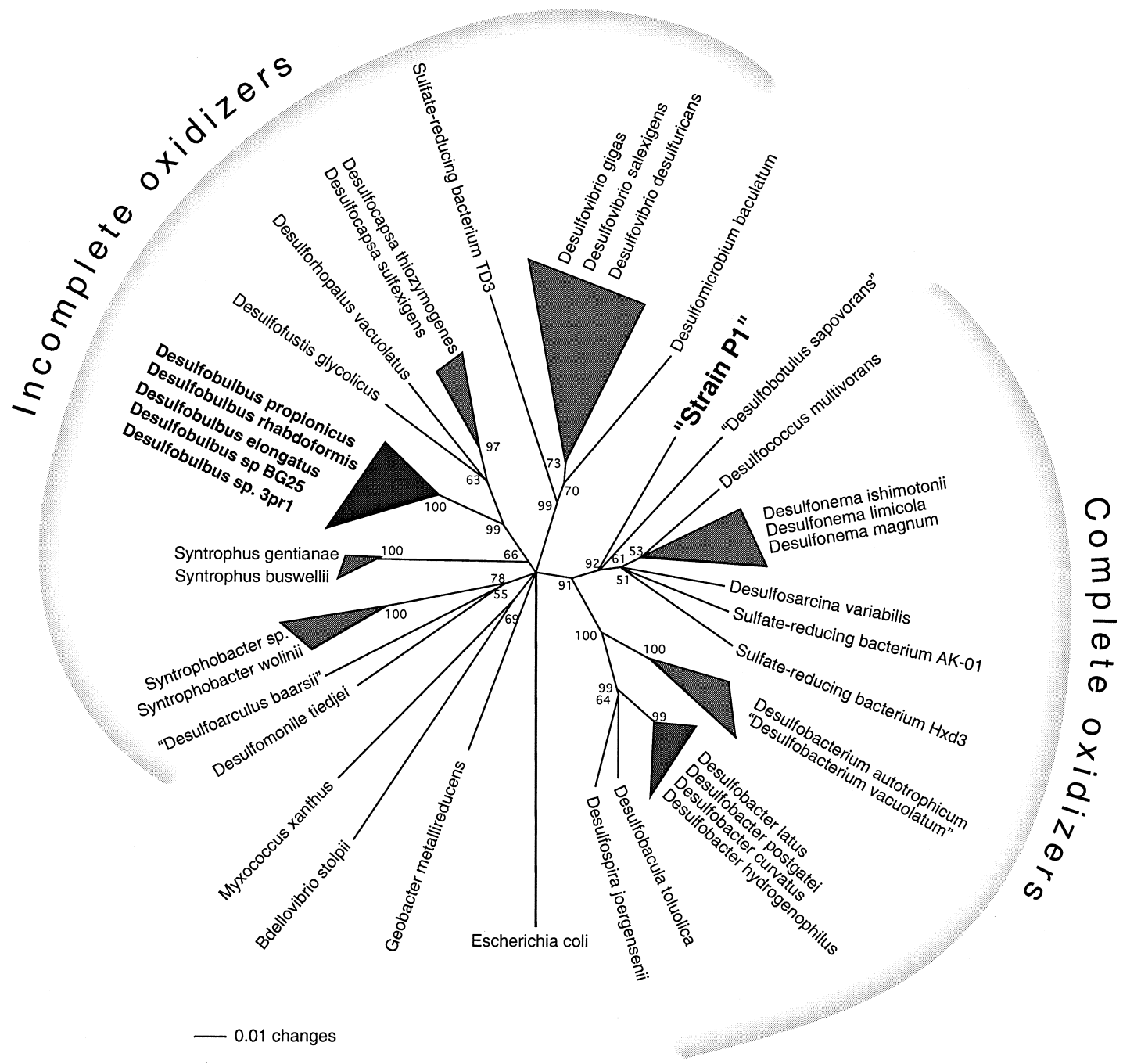

Fig. 3. Phylogenetic tree based on SSU rRNA sequences showing the relationship between strain $\mathrm{P} 1^{\top}$ and its closest relatives as well as other reference organisms of the $\delta$-Proteobacteria. The SSU rRNA sequence of $E$. coli was used as outgroup. The tree was constructed using a heuristic search algorithm with default settings for the distance matrix analysis in PAUP* 4.0. Only nodes supported by bootstrap numbers greater than $50 \%$ are shown. Other nodes are represented as multifurcations. Numbers on nodes indicate bootstrap values and 1404 unambiguous aligned nucleic acids of the SSU rDNA were included in the analysis. Bar, mean number of substitutions per site.

cultures where cells appeared grey. In these cultures, cell stages were observed which contained shiny inclusions. Growing cells contained large numbers of spherical inclusions that were $0 \cdot 1-0 \cdot 2 \mu \mathrm{m}$ in diameter (Fig. 2). The nature of the inclusion could not be elucidated. However, glucose formation from either polyglucose or poly- $\beta$-hydroxybutyrate was not detected. Cells stained Gram-negative.

\section{Physiological and biochemical characteristics}

Strain $P 1^{T}$ used sulfate $(20 \mathrm{mM})$, sulfite $(5 \mathrm{mM})$ and elemental sulfur as electron acceptors with propionate $(15 \mathrm{mM})$ as electron donor. Nitrate $(2 \mathrm{mM})$ and thiosulfate $(20 \mathrm{mM})$ were not used. Propionate (15 $\mathrm{mM})$, alanine $(15 \mathrm{mM})$, ethanol $(15 \mathrm{mM})$, butanol
$(10 \mathrm{mM})$, pyruvate $(5 \mathrm{mM})$, succinate $(10 \mathrm{mM})$ and fumarate $(10 \mathrm{mM})$ served as carbon sources and electron donors when sulfate was present as electron acceptor. Hydrogen was also used as an electron donor; growth with $\mathrm{H}_{2}$ was only observed in the presence of acetate as carbon source. The following compounds were not utilized as electron donors: acetate $(15 \mathrm{mM})$, butyrate $(5 \mathrm{mM})$, long-chain fatty acids $\left(\mathrm{C}_{5}-\mathrm{C}_{16} ; 2 \mathrm{mM}\right)$, 1-propanol $(5 \mathrm{mM})$, 2-propanol $(5 \mathrm{mM})$, lactate $(15 \mathrm{mM})$, glucose $(5 \mathrm{mM})$, fructose $(5 \mathrm{mM})$, sucrose $(5 \mathrm{mM})$, benzoate $(1 \mathrm{mM})$, nicotinate $(1 \mathrm{mM})$, choline $(5 \mathrm{mM}), \alpha$-ketoglutarate $(5 \mathrm{mM})$ and betaine $(5 \mathrm{mM})$. A fermentative type of metabolism was not observed.

Strain $\mathrm{P} 1^{\mathrm{T}}$ required brackish-marine medium for growth (DSMZ signature 198 for Desulfosarcina 


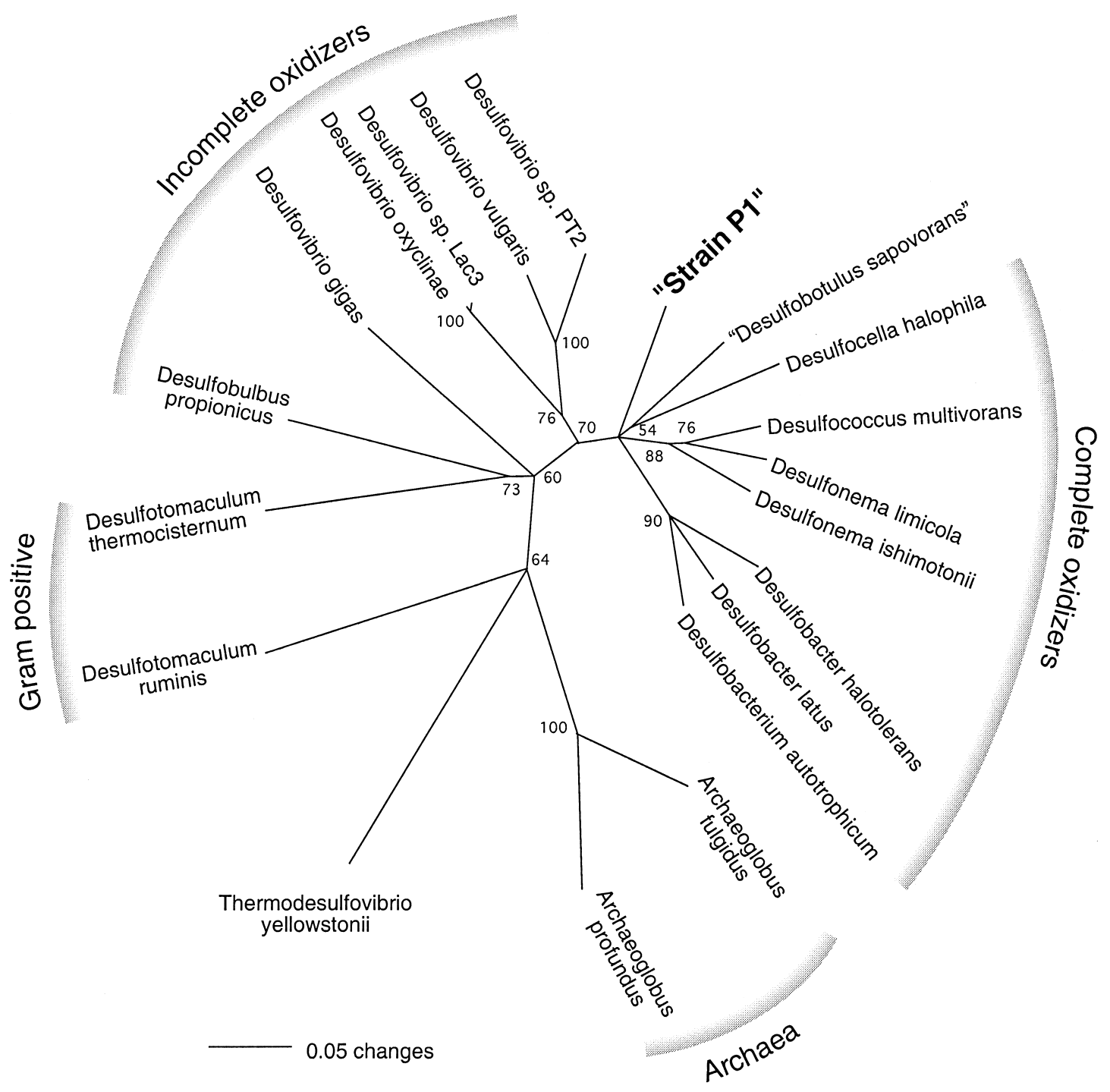

Fig. 4. Phylogenetic tree based on DSR gene amino acid sequences showing the relationship between strain $P 1^{\top}$ and its closest relatives as well as other sulfate reducing bacteria. The DSR gene sequence of Archaeoglobus sp. was used as outgroup. The tree was constructed using a heuristic search algorithm with default settings for the distance matrix analysis in PAUP* 4.0. Only nodes supported by bootstrap numbers greater than $50 \%$ are shown. Other nodes are represented as multifurcations. Numbers on nodes indicate bootstrap values and 252 unambiguous aligned amino acids of the DSR gene were included in the analysis. Bar, mean number of substitutions per site.

variabilis). However, $\mathrm{CaCl}_{2}$ and $\mathrm{MgCl}_{2}$ at concentrations of 10 and $50 \mathrm{mM}$, respectively, were required for optimal growth. Growth was inhibited at $\mathrm{CaCl}_{2}$ and $\mathrm{MgCl}_{2}$ concentrations below 4 and $20 \mathrm{mM}$, respectively. Optimum growth rate of strain $\mathrm{P} 1^{\mathrm{T}}$ was observed at $\mathrm{pH} 7 \cdot 2-7 \cdot 4$ and at $20^{\circ} \mathrm{C}$. Growth occurred between 30 and $8^{\circ} \mathrm{C}$. At $30^{\circ} \mathrm{C}$, cells were generally bigger than those grown at $25^{\circ} \mathrm{C}$ or lower. Cells were catalase-positive. Strain $\mathrm{P} 1^{\mathrm{T}}$ was desulfoviridin-negative.

\section{Propionate metabolism and $\mathbf{G}+\mathbf{C}$ content}

Propionate was incompletely oxidized to acetate in the presence of sulfate; $1 \mathrm{~mol}$ acetate was formed from
$1 \mathrm{~mol}$ propionate. The following equation for propionate oxidation is proposed:

$$
\begin{aligned}
& 4 \mathrm{CH}_{3} \mathrm{CH}_{2} \mathrm{COO}^{-}+3 \mathrm{SO}_{4}^{2-} ? 4 \mathrm{CH}_{3} \mathrm{COO}^{-}+4 \mathrm{HCO}_{3}^{-} \\
& +3 \mathrm{HS}^{-}+\mathrm{H}^{+}\left[\Delta G^{0 \prime}=-38 \cdot 1 \mathrm{~kJ}(\mathrm{~mol} \text { propionate }\right. \\
& \text { oxidized } \left.)^{-1}\right] .
\end{aligned}
$$

The amount of propionate that was consumed for cell material synthesis was calculated by the following equation:

$$
\begin{aligned}
& 17 \mathrm{CH}_{3} \mathrm{CH}_{2} \mathrm{COO}^{-}+5 \mathrm{HCO}_{3}^{-}+15 \mathrm{H}_{2} \mathrm{O} ? 14 \mathrm{C}_{4} \mathrm{H}_{7} \mathrm{O}_{3} \\
& +22 \mathrm{OH}^{-} ;
\end{aligned}
$$

thus, $0.0118 \mathrm{mmol}$ propionate are required for $1.0 \mathrm{mg}$ (dry weight) cells and $3.25 \mathrm{~g}$ biomass was produced per 
mole propionate. Consequently, $4 \cdot 3 \%$ consumed propionate was incorporated into cell biomass.

The $\mathrm{G}+\mathrm{C}$ content of DNA of strain $\mathrm{P} 1^{\mathrm{T}}$ was $53 \cdot 4 \pm 0 \cdot 3$ $\mathrm{mol} \%$ (mean value of three determinations).

\section{Phylogeny based on comparison of SSU rDNA}

Strain $\mathrm{P} 1^{\mathrm{T}}$ is a member of the $\delta$-Proteobacteria. It belongs to a coherent group of micro-organisms, which consists of the genera Desulfosarcina, Desulfococcus and Desulfonema (Fig. 3). All organisms of that group oxidize long-chain fatty acids and, with the exception of 'Desulfobotulus sapovorans', the oxidation of organic electron donors to $\mathrm{CO}_{2}$ is complete. Within this phylogenetic cluster, strain $\mathrm{P}^{\mathrm{T}}$ was more closely related to the genus Desulfosarcina and to the species Desulfosarcina variabilis $(91 \cdot 1 \%)$ than to members of the other genera.

\section{Phylogeny based on comparison of DSR genes}

Phylogeny derived from DSR sequences was largely congruent with SSU-based phylogeny (Fig. 4). Since the number of DSR sequences that are available for comparison is lower than the number of SSU rRNA sequences, it is not surprising that minor differences in the branching pattern were observed for the two trees. Nonetheless, the basic association of strain $\mathrm{P}^{\mathrm{T}}$ with the genera Desulfosarcina, Desulfococcus and Desulfonema and not with Desulfobulbus was supported by DSR sequence analysis.

\section{DISCUSSION}

In this communication, a newly isolated marine sulfate-reducing bacterium, designated strain $\mathrm{P}^{\mathrm{T}}$, is reported. Like members of the related genera Desulfobulbus and Desulforhopalus, strain $\mathrm{P} 1^{\mathrm{T}}$ used propionate as electron donor and carbon source and oxidized it incompletely to acetate and $\mathrm{CO}_{2}$ with sulfate as electron acceptor (Widdel \& Pfennig, 1982; Lien et al., 1998; Isaksen \& Teske, 1996). As with members of Desulfobulbus and Desulforhopalus, strain $\mathrm{P}^{\mathrm{T}}$ also shared the ability to utilize lactate, ethanol, pyruvate, fumarate and hydrogen (Lien et al., 1998; Isaksen \& Teske, 1996). However, in contrast to members of these genera, strain $\mathrm{P}^{\mathrm{T}}$ was not able to grow by a fermentative type of metabolism (Laanbroek et al., 1982; Isaksen \& Teske, 1996) or to use thiosulfate as electron acceptor. The large inclusions that were observed in cells of strain $\mathrm{P} 1^{\mathrm{T}}$ were not reported from any of the known representatives of the genera Desulfobulbus and Desulforhopalus. Smaller inclusions containing polyglucose were, however, found in cells of Desulfobulbus propionicus (Stams et al., 1983). Identification of the compound(s) that constituted the inclusions of strain $\mathrm{P}^{\mathrm{T}}$ awaits further investigations. Despite the fact that strain $\mathrm{P} 1^{\mathrm{T}}$ shared many phenotypic traits with members of the genera Desulfobulbus and Desulforhopalus, it was only distantly related to them. A comparison of the SSU rDNA revealed that strain $\mathrm{P} 1^{\mathrm{T}}$ phylogenetically fell into the Desulfosarcina/Desulfococcus/Desulfosarcina assemblage, where it was most closely related to Desulfosarcina variabilis with a sequence similarity of $91 \cdot 1 \%$. This affiliation was also supported by DSR sequence similarities. Physiologically, members of the Desulfosarcina/Desulfococcus/Desulfonema assemblage are generally characterized by their capacity to oxidize their energy sources completely to $\mathrm{CO}_{2}$. However, like strain $\mathrm{P} 1^{\mathrm{T}}$, 'Desulfobotulus sapovorans' represents an exception to the rule (Widdel \& Bak 1992). 'Desulfobotulus sapovorans' is also an incomplete oxidizer but, in contrast to strain $\mathrm{P} 1^{\mathrm{T}}$, 'Desulfobotulus sapovorans' degrades long-chain fatty acids, a metabolic trait that is characteristic for genera within this assemblage. In addition to long-chain fatty acids, members of the assemblage utilize a wide range of substrates, including aromatic compounds and alkanes (So \& Young, 1999). In contrast, the range of substrates used by strain $\mathrm{P}^{\mathrm{T}}$ was relatively restricted and in good agreement with the substrate pattern of the genera Desulfobulbus and Desulforhopalus.

On the basis of a combined phenotypic and genotypic characterization, strain $\mathrm{P} 1^{\mathrm{T}}$ was placed in a new genus for which the name Desulfomusa gen. nov. is proposed. Strain $\mathrm{P} 1^{\mathrm{T}}$ is proposed as the type strain of a novel species within this genus with the species name Desulfomusa hansenii sp. nov.

\section{Description of Desulfomusa gen. nov.}

Desulfomusa (De.sul.fo.mu'sa. L. de from; L. n. sulfur sulfur; M.L. n. musa banana; N.L. fem. n. Desulfomusa banana-shaped bacterium that reduces sulfate).

Strain $\mathrm{P} 1^{\mathrm{T}}$ uses sulfate as electron acceptor and reduces it to sulfide. Propionate is incompletely oxidized to acetate and $\mathrm{CO}_{2}$. Long-chain fatty acids, acetate and aromatic compounds are not oxidized. Sulfate, sulfite and elemental sulfur serve as electron acceptors. A fermentative type of metabolism is not observed. Desulfomusa belongs to the $\delta$-Proteobacteria; to date the closest relative is Desulfosarcina variabilis. According to Rule 20c of the Bacteriological Code (Lapage et al., 1992), Desulfomusa hansenii, the only species, is the type species of the genus.

\section{Description of Desulfomusa hansenii sp. nov.}

Desulfomusa hansenii (han.sen'i.i. N.L. gen. n. hansenii of Hansen, named to honour Theo Hansen of The Netherlands, who made important contributions to our understanding of the pathways of organic matter oxidation in sulfate-reducing bacteria).

Cells are straight to slightly curved $2-3 \times 3-6 \mu \mathrm{m}$. Motile by means of a single polar flagellum. Gramnegative. Cells contain spherical inclusions, which are $0 \cdot 1-0 \cdot 2 \mu \mathrm{m}$ in diameter. $\mathrm{CaCl}_{2}$ and $\mathrm{MgCl}_{2}$ are required for growth (optimum concentrations 10 and $50 \mathrm{mM}$, 
respectively). Propionate, alanine, ethanol, butanol, pyruvate, succinate and fumarate serve as carbon sources and electron donors. Optimal $\mathrm{pH}$ and temperature for growth are $7 \cdot 2-7 \cdot 4$ and $20{ }^{\circ} \mathrm{C}$, respectively. Grows diazotrophically. Catalase is present. The DNA $\mathrm{G}+\mathrm{C}$ content is $53.4 \mathrm{~mol} \%$ (determined by HPLC). Habitat: roots of the marine macrophyte Zostera marina. Type strain is $\mathrm{P} 1^{\mathrm{T}}\left(=\mathrm{DSM} 12642^{\mathrm{T}}=\mathrm{ATCC}\right.$ $\left.700811^{\mathrm{T}}\right)$.

\section{ACKNOWLEDGEMENTS}

K.F. and N.B. R. acknowledge the skilful assistance of Tove Wiegers and Dorthe Ganzhorn. We thank Dr Jørgen Mørup Madsen for helping us with TEM and specimen preparation. This research was funded by the EU research program 'Preserving the Ecosytem' under the ROBUST project contract ENV4-CT96-0218. The contribution from ELOISE no. 226. Staten's Naturvidenskabelige Forskningsråd, Denmark supported the molecular work. We acknowledge the comments of Theo Hansen and an anonymous reviewer who helped to improve the manuscript.

\section{REFERENCES}

Blaabjerg, V. \& Finster, K. (1998). Sulfate reduction associated with roots and rhizomes of the marine macrophyte Zostera marina. Aquat Microb Ecol 15, 311-314.

Blaabjerg, V., Mouritsen, K. \& Finster, K. (1998). Diurnal cycles of sulfate reduction rates in sediments of Zostera marina-bed (Denmark). Aquat Microb Ecol 15, 97-102.

Coates, J. D., Lonegran, D. J., Philips, E. J. P., Jenter, H. \& Lovley, D. R. (1995). Desulfuromonas palmitatis sp. nov., a marine dissimilatory $\mathrm{Fe}$ (III) reducer that can oxidize long-chain fatty acids. Arch Microbiol 164, 406-413.

Hines, M., Evans, R. S., Sharak Genthner, B. R., Willis, S. G., Friedmann, S., Rooney-Varga, J. N. \& Devereux, R. (1999). Molecular phylogeny and biogeochemical studies of sulfatereducing bacteria in the rhizosphere of Spartina alteriniflora. Appl Enivron Microbiol 65, 2209-2216.

Isaksen, M. \& Finster, K. (1996). Sulfate reduction in the root zone of the seagrass Zostera noltii on the intertidal flats of a coastal lagoon (Arcachon, France). Mar Ecol Prog Ser 137, $187-194$

Isaksen, M. \& Teske, A. (1996). Desulforhopalus vacuolatus gen. nov., sp. nov., a new moderately psychrophilic sulfate-reducing bacterium with gas vacuoles isolated from a temperate estuary. Arch Microbiol 166, 160-168.

Laanbroek, H. J., Abee, T. \& Voogd, I. L. (1982). Alcohol conversions by Desulfobulbus propionicus Lindhorst in the presence and absence of sulfate and hydrogen. Arch Microbiol 133, 178-184.

Lane, D. J. (1991). 16S/23S rRNA sequencing. In Nucleic Acid Techniques in Bacterial Systematics, pp. 115-175. Edited by E. Stackebrandt \& M. Goodfellow. Chichester: John Wiley.
Lapage, S. P., Sneath, P. H. A., Lessel, E. F., Skerman, V. B. D., Seeliger, H. P. R. \& Clark, W. A. (editors) (1992). International Code of Nomenclature of Bacteria (1990 Revision). Bacteriological Code. Washington, DC: American Society for Microbiology.

Lien, T., Madsen, M., Steen, I. H. \& Gjerdevik, K. (1998). Desulfobulbus rhabdoformis sp. nov., a sulfate reducer from a water-oil separation system. Int J Syst Bacteriol 48, 469-474.

Mesbah, M., Premachandran, U. \& Whitman, W. B. (1989). Precise measurement of the $\mathrm{G}+\mathrm{C}$ content of deoxyribonucleic acid by high-performance liquid chromatography. Int J Syst Bacteriol 39, 159-167.

Nielsen, J. T., Liesack, W. \& Finster, K. (1999). Desulfovibrio zosterae sp. nov., a new sulfate reducer isolated from surfacesterilized roots of the seagrass Zostera marina. Int $J$ Syst Bacteriol 49, 859-865.

Nielsen, L. B., Finster, K., Welsh, D. T., Donelly, A., Herbert, R. A., de Wit, R. \& Lomstein, B. A. (2001). Sulfate reduction and nitrogen fixation rates associated with roots, rhizomes and sediments from Zostera noltii and Spartina maritima meadows. Environ Microbiol 3, 72-78.

Rooney-Varga, J. N., Devereux, R., Evans, R. S. \& Hines, M. E. (1997). Seasonal changes in the relative abundance of uncultivated sulfate-reducing bacteria in a salt marsh sediment and in the rhizosphere of Spartina alterniflora. Appl Environ Microbiol 63, 3895-3901.

So, C. M. \& Young, L. Y. (1999). Isolation and characterization of a sulfate-reducing bacterium that anaerobically degrades alkanes. Appl Environ Microbiol 65, 2969-2976.

Stams, A. J. M., Veenhuis, M., Weenk, G. H. \& Hansen, T. A. (1983). Occurrence of polyglucose as a storage polymer in Desulfovibrio and Desulfobulbus propionicus. Arch Microbiol 136, 54-59.

Strunk, O. \& Ludwig, W. (1998). ARB - a software environment for sequence data. Department of Microbiology, Technical University of Munich, Munich, Germany.

Swofford, D. L. (2000). PAUP*. Sunderland, MA: Sinauer Associates.

Tamaoka, J. \& Komagata, K. (1984). Determination of DNA base composition by reversed-phase high-performance liquid chromatography. FEMS Microbiol Lett 25, 125-128.

Wagner, M., Roger, A. J., Flax, J. L., Brusseau, G. A. \& Stahl, D. A. (1998). Phylogeny of dissimilatory sulfite reductase supports an early origin of sulfate respiration. J Bacteriol 180, 2975-2982.

Widdel, F. \& Bak, F. (1992). Gram-negative mesophilic sulfatereducing bacteria. In The Prokaryotes, 2nd edn, pp. 3352-3378. Edited by A. Balows, H. G. Trüper, M. Dworkin, W. Harder \& K.-H. Schleifer. New York: Springer.

Widdel, F. \& Pfennig, N. (1982). Studies on dissimilatory sulfatereducing bacteria that decompose fatty acids. II. Incomplete oxidation of propionate by Desulfobulbus propionicus gen. nov., sp. nov. Arch Microbiol 131, 360-365.

Widdel, F. \& Pfennig, N. (1984). Dissimilatory sulfate- or sulphurreducing bacteria. In Bergey's Manual of Systematic Bacteriology, vol. 1, pp. 663-679. Edited by N. R. Krieg \& J. G. Holt. Baltimore: Williams \& Wilkins.

Visuvanathan, S., Moss, M. T., Stanford, J. L., Hermon-Taylor, J. \& McFadden, J. J. (1989). Simple enzymatic method for isolation of DNA from diverse bacteria. J Microbiol Methods 10, 59-64. 